\title{
Evaluating vertical migration behavior of harmful raphidophytes in the Delaware Inland Bays utilizing quantitative real-time PCR
}

\author{
S. M. Handy ${ }^{1}$, K. J. Coyne ${ }^{1}$, K. J. Portune ${ }^{1}$, E. Demir ${ }^{1}$, M. A. Doblin ${ }^{2}$, C. E. Hare ${ }^{1}$, \\ S. C. Cary $^{1}$, D. A. Hutchins ${ }^{1, *}$ \\ ${ }^{1}$ University of Delaware, Graduate College of Marine Studies, 700 Pilottown Road, Lewes, Delaware 19958, USA \\ ${ }^{2}$ Institute of Water and Environmental Resource Management, Department of Environmental Science, \\ University of Technology, Westbourne St, Gore Hill, New South Wales 2065, Australia
}

\begin{abstract}
Mixed blooms of 4 species of harmful raphidophytes (Chattonella cf. verruculosa, Chattonella subsalsa, Heterosigma akashiwo, and Fibrocapsa japonica) occur in the shallow (1 to $2 \mathrm{~m}$ ) Delaware Inland Bays (DIB), USA. Raphidophytes vertically migrate in other deeper water ecosystems to utilize deep nutrient stocks at night, and thus obtain an advantage over non-migrating algae. Anoxic DIB sediments release high levels of bioavailable phosphate, which could potentially be used by vertically migrating flagellates. This study aimed to characterize and understand the migration patterns of DIB raphidophytes, and determine whether benthic phosphate fluxes could provide the cells with P. We demonstrated vertical migration of isolated DIB raphidophyte cultures in the laboratory, where differences in the response of C. subsalsa and H. akashiwo to light:dark period manipulations suggested possible differences in external versus endogenous regulation of migration behavior in the 2 species. Natural blooms in the field (enclosed in a mesocosm system) also exhibited patterns of diel vertical migration, as determined by quantitative real-time PCR (QPCR) used to enumerate the diel vertical distributions of each species. Our data suggested that these 2 photoautotrophic species spend daylight hours near the surface and are found directly on the sediment surface at night. However, diel changes in particulate C:P ratios did not support the hypothesis that there is preferential uptake of sedimentary phosphate at night. Our results also suggested that the migration behavior may have important implications for designing sampling strategies for monitoring programs. QPCR has a number of decisive advantages over traditional microscopic counting methods, making this a powerful tool for fine spatial and temporal scale detection and enumeration of vertically migrating harmful algal species.
\end{abstract}

KEY WORDS: Raphidophytes · Delaware Inland Bays · Vertical migration · Quantitative real-time PCR $\cdot$ Chattonella subsalsa $\cdot$ Heterosigma akashiwo

\section{INTRODUCTION}

Raphidophytes have been responsible for mass mortalities of fish in many areas of the world (Odebrecht \& Abreu 1995, Munday \& Hallegraeff 1998) including Delaware's Inland Bays (DIB) (Bourdelais et al. 2002). Harmful effects by members of this class are due to both toxin production (Kim et al. 1999, Haque \& Onoue 2002) and asphyxiation in fish (Lee et al. 2003). Occurr- ences of toxic bloom events involving this class of algae have been increasing on both spatial and temporal scales. Recently, potentially harmful species from the class Raphidophyceae have been identified in the waters of the DIB. Four different species belonging to this group have been identified: Chattonella cf. verruculosa, Chattonella subsalsa, Heterosigma akashiwo, and Fibrocapsa japonica (Whereat 2003). Blooms have occurred for 5 consecutive summers since they were 
first discovered in 2000. A total of 463 occurrences of raphidophytes were confirmed by microscopy in 2003 alone (Whereat 2003). At least one of these species, $C$. cf. verruculosa, has been associated with the potent neurotoxin brevetoxin during DIB bloom events (Bourdelais et al. 2002).

It is apparent that 2 or more of these 4 species of raphidophytes are often found together at substantial concentrations in the DIB. Reports indicate that mixed raphidophyte blooms in the DIB are a common occurrence (Whereat 2003). This suggests the opening of a niche in the DIB that favors the growth of this class of algae as a whole, rather than selection for a single species as in most harmful algal bloom (HAB) events (Smayda \& Borkman 2003). It also raises questions about possible competitive interactions and mechanisms of niche separation between the 4 sympatric raphidophytes.

The DIB are comprised of 3 connected bodies of water: the Rehoboth Bay, the Indian River Bay, and the Little Assawoman Bay. The DIB are poorly flushed, shallow estuaries with an average low tide depth of 1 to $2.5 \mathrm{~m}$ (Horsley \& Witten Inc 1998, Price 1998). Despite being shallow, the DIB become stratified in the summertime in terms of nutrients, salinity, and temperature (D. A. Hutchins \& K. J. Coyne unpubl.). There can be strong vertical salinity ( $\Delta 9 \mathrm{psu}$ ) and temperature $\left(\Delta 4^{\circ} \mathrm{C}\right)$ gradients between surface and bottom waters, especially in the tributaries, as a result of many factors including freshwater runoff.

The DIB have been considered highly eutrophied for at least the last 20 yr (Price 1998). Agribusiness operations, nutrient contaminated groundwater, and sewage treatment plant effluents are all substantial sources of nutrient inputs to the DIB. This has resulted in a high frequency of phytoplankton blooms, especially during the summer months when nutrient loading is maximal and temperature and light levels are best suited for phytoplankton growth (Price 1998, Rozan et al. 2002). These nitrogen-enriched sources of nutrients to the DIB may create seasonal phosphorus limitation. However, DIB sediments become sulfidic due to pronounced anoxia, releasing usable phosphate that is known to support benthic macroalgal growth (Rozan et al. 2002), and that could possibly serve as a source of bioavailable $\mathrm{P}$ to algae in the water column.

Flagellates such as raphidophytes have a potential advantage over some non-swimming phytoplankton because they can vertically migrate relatively quickly throughout the water column. Diel vertical migration (DVM) is a well-known phenomenon in many different planktonic organisms, including photosynthetic flagellates. Two main theories on the advantages of having a diel migration cycle are (1) that it allows organisms to take advantage of nutrients in the lower water column
(Cullen \& Horrigan 1981, Kimura et al. 1999), and (2) it allows escape from grazing pressure (Watanabe et al. 1995). Raphidophytes are also known to produce reactive oxygen species (ROS) (Yang et al. 1995, Twiner \& Trick 2000), which may have adverse physiological effects, such as necrosis of cell membranes (Marshall et al. 2005). It has recently been suggested that since ROS production is largely carried out in near-surface waters during the day (Kim et al. 2004, 2005), vertically migrating raphidophytes would avoid the toxic effects of ROS by migrating downwards at night.

Two major cues and mechanisms found to affect DVM are phototaxis (the movement of an organism towards or away from a source of light) and geotaxis (the movement of an organism in response to gravity). Another possible explanation is that cells have their own endogenous clock, based on circadian rhythms and directed by gravity or light. These are rhythms that continue independently of environmental changes and have a periodicity of about $24 \mathrm{~h}$, though they can be reset by a change in the natural light:dark cycle (Fogg \& Thake 1987).

Most DVM studies have focused on dinoflagellates, in water greater than $10 \mathrm{~m}$ deep (Eppley et al. 1968, Cullen \& Horrigan 1981, Flaim et al. 2003). Watanabe et al. (1995) examined vertical migration of raphidophytes in both laboratory and mesocosm experiments and suggested that DVM provides an advantage for nutrient acquisition over non-swimming diatom populations in deeper ocean waters. At least 1 raphidophyte species (Chattonella antiqua) is able to traverse large gradients of temperature and salinity when it migrates at night to deeper waters (Kimura et al. 1999). However, it remains unclear why this strategy would be advantageous in a very shallow water column as is found in the DIB.

Enumeration of raphidophytes via microscopy is difficult as the cells are extremely fragile, and lyse quickly (within 2 to $3 \mathrm{~d}$ ) when they are exposed to standard preservatives such as glutaraldehyde or Lugol's. Microscopic counts of raphidophytes can only be carried out using live cells in real time, or when preserved for a very short amount of time. Experiments involving intensive sampling for abundance estimates are difficult, especially for field samples that contain complex populations. To overcome this difficulty, we chose to use alternative enumeration methods in our field experiments.

Quantitative real-time polymerase chain reaction (QPCR) is a relatively new molecular method (Heid et al. 1996). Its application for quantitative analysis of raphidophyte species has recently been described by Coyne et al. (in press). With carefully validated probes, QPCR allows unambiguous counts of particular species in a mixed community (Popels et al. 2003, Coyne et 
al. in press). QPCR can potentially be used to track the movement of raphidophytes in the water column. Filtered samples can be stored frozen for later DNA extraction and amplification, making intensive experimental sampling possible. This is the first example of QPCR being used to track cell abundances in a mesocosm experiment.

This study attempted to determine if this consortium of raphidophytes migrates in the DIB and, if so, what types of selective advantages these species might obtain by vertically migrating in a very shallow (1 to $2 \mathrm{~m}$ ) water column. We successfully used QPCR methods to track the vertical movements of Heterosigma akashiwo and Chattonella subsalsa in mesocosm-enclosed natural blooms of raphidophytes from the DIB. The goal of our study was to help understand what role DVM may play in allowing these species to coexist and form mixed blooms, thus becoming ecologically dominant over other non-harmful phytoplankton species.

\section{MATERIALS AND METHODS}

Laboratory column experiments. Using columns constructed to represent the average depth at summer sampling sites in the DIB $(\sim 1 \mathrm{~m})$, we conducted a series of vertical migration experiments in triplicate. Experiments were carried out with DIB isolates, including Chattonella subsalsa (CCMP 2191) and Heterosigma akashiwo (CCMP 2393). Cultures had been maintained for $\sim 2 \mathrm{yr}$ in nutrient-replete $\mathrm{f} / 2$ (Guillard \& Ryther 1962) on a 12:12 h light:dark cycle before use in experiments. The columns were constructed out of $0.91 \mathrm{~m}$ opaque polyvinyl chloride plastic and had a diameter of $10.6 \mathrm{~cm}$. Each column held $7.4 \mathrm{l}$ of $\mathrm{f} / 2$ medium (Guillard \& Ryther 1962) and prepared culture. On each column were 4 sampling ports. Ports were located at the surface and 12.7, 49.5 and $86.7 \mathrm{~cm}$ from the top of the column. Fluorescent lights were hung above the columns with a surface light intensity of $\sim 220 \mu \mathrm{E}$. Inside the columns, light intensities were $\sim 135$ and $\sim 25 \mu \mathrm{E}$ at the middle ports, and $\sim 7 \mu \mathrm{E}$ at the lowest port.

Laboratory experiments. Expt 1-presence of DVM: Batch cultures were diluted with $\mathrm{f} / 2$ media (triplicate columns for each species) to obtain starting cell

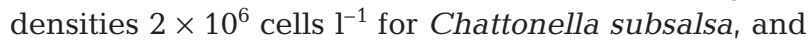
$6 \times 10^{6}$ cells $^{-1}$ for Heterosigma akashiwo, which correspond to pre-bloom to early bloom levels. Cultures were then allowed to grow for $2 \mathrm{~d}$ under a $14: 10 \mathrm{~h}$ light:dark cycle. The sampling began at 07:00 $\mathrm{h}(3 \mathrm{~h}$ after lights were turned on) and continued for $48 \mathrm{~h}$ at $6 \mathrm{~h}$ intervals. To replace volume lost to sampling, medium was added back to the bottom of the column using a syringe and a tygon tube that was run to the bottom of the column; this was in place at the beginning of the experiment and was used to inject medium slowly back into the column to maintain the medium surface at the very top of the column. In vivo chlorophyll a (chl a) was determined by fluorometery using a Turner A10 fluorometer (Brand et al. 1981). Triplicate algal cell count samples were preserved with $0.1 \%$ glutaraldehyde and stored in the dark at $4{ }^{\circ} \mathrm{C}$ until analysis with light microscopy within $4 \mathrm{~d}$. Though some cells had changed shape, they were visibly intact. Triplicate samples were counted using the average of 10 fields at $100 \times$ magnification on a Speirs-Levy counting chamber.

Expt 1-endogenous rhythms: The second stage of the experiment was to determine whether the light: dark cycle directly regulates the movement of the phytoplankton. After the collection of the $48 \mathrm{~h}$ data set in a 14:10 h light:dark cycle, samples were put in continuous darkness for $2 \mathrm{~d}$. After the initial $48 \mathrm{~h}$ in darkness, samples were taken every $6 \mathrm{~h}$ for an additional $24 \mathrm{~h}$ with the lights off, for a total experimental time of $72 \mathrm{~h}$.

Expt 2-light dependence of DVM: The final laboratory experiment used separate triplicate columns for each species (Chattonella subsalsa and Heterosigma akashiwo) incubated in continual light. The columns had starting cell densities of $1 \times 10^{6}$ cells l$^{-1}$ for C. subsalsa, and $3 \times 10^{6}$ cells $^{-1}$ for $H$. akashiwo. Comparison of in vivo measurements to cell counts in this experiment showed that both methods gave an accurate estimation of algal distribution within the columns (data not shown). Cells were allowed to acclimate for $1 \mathrm{~d}$ in a 14:10 h light:dark cycle as before (with no sampling), then the columns were left in continual light for $48 \mathrm{~h}$. Once acclimated, sampling occurred every $6 \mathrm{~h}$ for $24 \mathrm{~h}$. Samples were taken for cell counts and in vivo chl a. At the end of the laboratory Expt 2, H. akashiwo cells were sampled from the very bottom of the column using the same tygon tubing that was used for adding medium back to the system.

Field mesocosm experiments. Expts 1 and 2-Chattonella subsalsa and mixed raphidophyte blooms: In the summer of 2004, 2 experiments were carried out in the DIB utilizing in situ mesocosm enclosures during naturally occurring raphidophyte blooms. Field Expt 1 was conducted in a Rehoboth Bay canal between 28 and 31 July 2004, entrapping a bloom that consisted

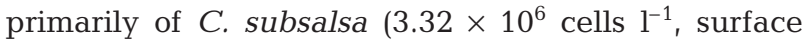
microscopic counts). Field Expt 2 was conducted in a Indian River Bay canal from 30 August to 3 September 2004, and consisted of a very dense C. subsalsa bloom

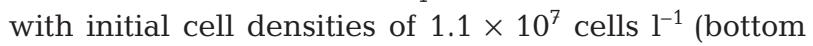
water column microscopic counts), but also included lower cell numbers of Heterosigma akashiwo, Fibrocapsa japonica, and C. cf. verruculosa. 


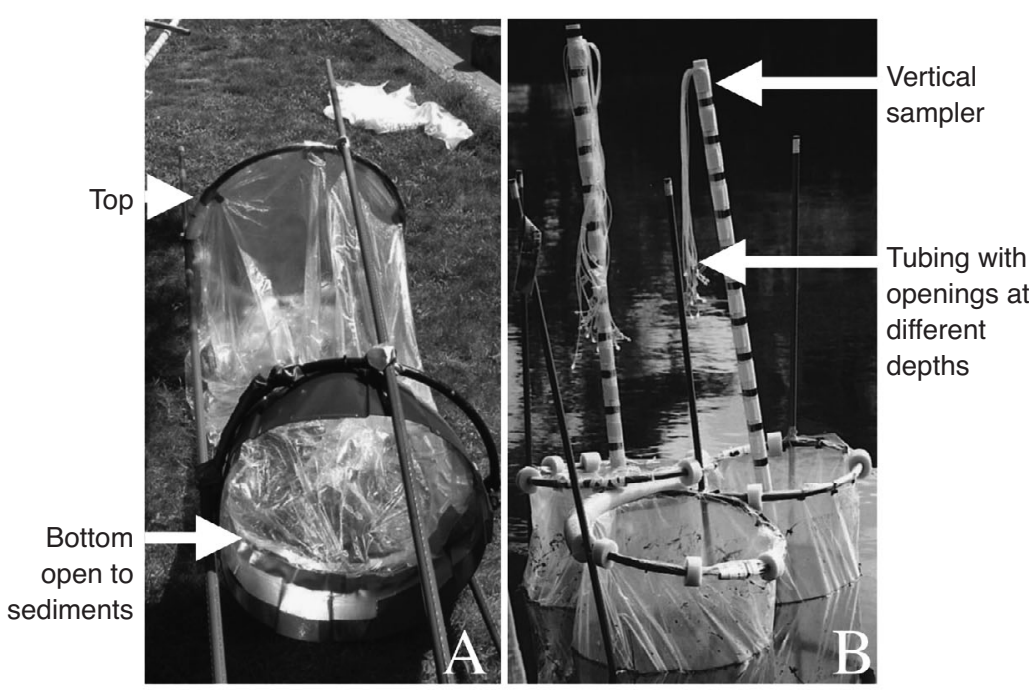

Fig. 1. Images of (A) in situ mesocosm system and (B) vertical sampling device used for field experiments

points $(07: 00,13: 00,17: 00$, and 23:00 h) over a period of 2 to $3 \mathrm{~d}$. Samples were filtered through a $0.2 \mu \mathrm{m}$ polycarbonate filter and then stored at $-20^{\circ} \mathrm{C}$ for dissolved nutrient analysis on a standard Alpkem autoanalyzer (Alpkem Corporation). Samples for particulate organic phosphate (POP) were collected according to Lebo \& Sharp (1992), and particulate organic nitrogen (PON) and carbon (POC) following the methods of Cutter \& Radford-Knoery (1991). Samples for PON and POC were analyzed using a Costech CHN analyzer (Costech Analytical Technologies). Water was vacuum-filtered onto $25 \mathrm{~mm} \mathrm{GF/F}$ glass fiber filter (Whatman) and extracted in $6 \mathrm{ml}$ $90 \%$ acetone in the dark at $-20^{\circ} \mathrm{C}$ for $24 \mathrm{~h}$ for chl a analysis using the non-acidified method (Welschmeyer 1994).

Molecular methods. Samples for DNA extraction were prefiltered ( $250 \mu \mathrm{m}$ Nitex) to remove large zooplankton and detritus, and then gently filtered under low vacuum pressure $(\sim 85 \mathrm{kPa})$ onto a $3 \mu \mathrm{m}$ polycarbonate filter. Due to time and

The mesocosm was created using clear 55 gal ( 208 1) plastic garbage bags made of polyethylene and rings of plastic tubing $(67.5 \mathrm{~cm}$ diameter $)$ with floats (Fig. 1). This mesocosm system enclosed the entire $\sim 1 \mathrm{~m}$ water column and was open to the natural sediments below. The mesocosms were submerged into the sediment $(\sim 30 \mathrm{~cm})$ and anchored using plastic garden poles. An additional plastic gardening pole was used to position a PVC pipe in the center of the mesocosm. Tygon tubing was run along the outsides of the PVC pipe and facilitated sampling at different depths by creating sampling ports every $10 \mathrm{~cm}$. Samples were taken using $60 \mathrm{ml}$ syringes every $10 \mathrm{~cm}$ (by gently pulling) from the water column through the tygon tube and then combined in bottles (representing top, middle, bottom) by gently mixing syringes full of water from each section. Integrating samples to the 3 general depth intervals was necessary to reduce sample numbers to manageable levels for processing, while at the same time allowing examination of the entire water column. Each sample then represented a mixture of the water in that section of the water column.

We used duplicate mesocosms for all experiments, and compared samples from inside each to outside conditions at the beginning ( $T_{10}$ and $T_{11}$ for Expts 1 and 2 , respectively) and end of the experiments ( $T_{50}$ and $T_{71}$ ). The mesocosms were allowed to equilibrate for $10 \mathrm{~h} \mathrm{(Expt} \mathrm{1)} \mathrm{and} 11 \mathrm{~h}$ (Expt 2) before time course sampling. Due to sampling intensity, we did not sample from both mesocosms at every time point. Samples were taken initially $\left(T_{0}\right)$ before the mesocosms were put into the water. Daily samples were taken at 4 time sample volume considerations, only 1 sample was taken from each sampling depth at each time point for DNA analysis. However, QPCR results using DNA extracted from triplicate water samples demonstrate good precision using this method (Coyne et al. in press).

Filters were submersed in CTAB buffer [100 mM Tris- $\mathrm{HCl}(\mathrm{pH} 8), 1.4 \mathrm{M} \mathrm{NaCl}, 2 \%$ (w/v) cetyltrimethylammonium bromide (CTAB), $0.4 \%$ (v/v) $\beta$-mercaptoethanol, $1 \%(\mathrm{w} / \mathrm{v})$ polyvinylpyrollidone, $20 \mathrm{mM}$ EDTA; Dempster et al. 1999] amended with $20 \mathrm{ng} \mathrm{ml}^{-1}$ pGEM plasmid (Promega) as an internal standard. The samples were then stored at $-80^{\circ} \mathrm{C}$ until extraction as described in Coyne et al. (2001), and DNA concentrations were determined by ultraviolet spectrophotometry. DNA was diluted 1:50 (for field Expt 1) or 1:200 (for field Expt 2) in LoTE [3 mM Tris- $\mathrm{HCl}$ ( $\mathrm{pH}$ 7.5), $0.2 \mathrm{mM}$ EDTA] to yield concentrations in the range of

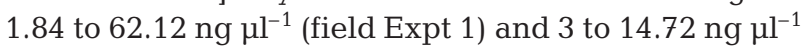
(field Expt 2) for use in the QPCR. Amplification efficiency by QPCR allows detection of a wide range of template concentrations, with demonstrated linearity over 7 orders of magnitude for these species as detailed in Coyne et al. (in press).

One of the primary goals of this study was to find the best way of enumerating raphidophyte species in complex communities from field experiments. Non-specific measurements like the in vivo chl a fluorescence measurements used in the unialgal laboratory culture experiments do not work for specific identification of mixed natural samples. Because of the difficulties in preserving these fragile species for extended sample storage periods, there is a need to develop and apply 
quantitative molecular assays for raphidophyte species in concert with traditional microscope techniques. If primer sets are available for the species of interest, molecular tools like QPCR can be employed to enumerate target species in natural samples (Coyne et al. 2001, in press, Popels et al. 2003). In addition to increased accuracy and sensitivity, a major advantage of this method is the ability to retain frozen DNA samples for long-term storage. Archived community DNA samples can also be assayed for other species of interest at a later time, as new primers become available.

QPCR was used to quantify the cell densities of Chattonella subsalsa in field Expts 1 and 2, and Heterosigma akashiwo in Expt 2 as described in Coyne et al. (in press), with an ABI Prism 7700 Sequence Detector (Applied Biosystems). Briefly, DNA was amplified in separate $25 \mu \mathrm{l}$ reactions, consisting of $2.5 \mu \mathrm{l}$ of diluted template DNA, $12.5 \mu$ of Taqman Universal Master Mix (Applied Biosystems), $0.9 \mu \mathrm{M}$ of species-specific forward primer, $0.9 \mu \mathrm{M}$ of species-specific reverse primer, and $0.2 \mu \mathrm{M}$ of species-specific probe. The primers and probe used for H. akashiwo were: Hs 1350F (5'-CTAAATAGTGTCGGTAATGCTTCT-3'), Hs 1705R (5'-GGCAAGTCACAATAAAGTTCCAT-3') and Hs Probe (5'-[FAM] CAACGAGTAACGACCTTTGCCGGAA [TAM]-3'). The primers and probe used for $C$. subsalsa were Cs 1350F (5' -CTAAATAGTGTGGGTAATGCTTAC-3'), Cs 1705R (5'-GGCAAGTCACAATAAAGTTCCAT-3') and Raph Probe (5'-[FAM]CAACGAGTACTTTCCTTGGCCGGAA[TAM]-3').

The internal standard was amplified in duplicate $25 \mu \mathrm{l}$ reactions, consisting of $12.5 \mu$ l Taqman Universal Master Mix, $0.9 \mu \mathrm{M}$ of pGEMR (5'-TGTGTGGAATTGTGAGCGGA-3'), $0.9 \mu \mathrm{M}$ M13F (5'-CCCAGTCACGACGTTGTAAAACG-3'), and $0.2 \mu \mathrm{M}$ of probe pGEM256R Probe (5'-[FAM]CACTATAGAATACTCAAGCTTGCATGCCTGCA[TAM]-3'). To enumerate the environmental samples, microscopic cell counts were made of Chattonella subsalsa in the initial bottom water sample from field Expt 2 and used for calibration. Heterosigma akashiwo concentrations were not high enough for accurate cell counts in field Expts 1 or 2, so a calibration sample was created from another local $H$. akashiwo field bloom. This allowed us to obtain an accurate estimate of the number of $H$. akashiwo cells from this experiment.

The cycle threshold $(\mathrm{Ct})$ values were determined for target DNA and internal standard from each water sample and the concentrations (cells $\mathrm{l}^{-1}$ ) of Chattonella subsalsa and Heterosigma akashiwo were calculated using the comparative $\mathrm{Ct}$ method as described in Livak \& Schmittgen (2001) and Coyne et al. (in press) for DIB samples. This method was validated by comparing the Ct values for the internal standard (pGEM) with the target DNA for each calibrator sample over a range of dilutions (Coyne et al. in press). For the method to be valid, the amplification efficiencies of target DNA and internal standard must be approximately equal.

\section{RESULTS}

\section{Laboratory experiments}

Expt 1 -presence of DVM and endogenous rhythms

This laboratory column experiment showed that DIB isolates Chattonella subsalsa and Heterosigma akashiwo demonstrated similar DVM behavior in a uniform water column under controlled culture conditions (Fig. 2). Field samples collected in the past have frequently shown aggregation at the surface in the morning, and by evening cells appeared mixed in the water column (bottle), with no thin layers visible at the bottom at night. This suggests that in these experiments we would have been able to track the cells accurately. Both species appeared at the surface at 07:00 $\mathrm{h}$ (Figs. $2 \& 3$ ), and moved to the bottom of the water column (below the bottom port) by 19:00 $\mathrm{h}$ (data not shown). Surface cell densities steadily decreased throughout the day, and then increased again by the following morning at 07:00 h (Figs. $2 \& 3$ ). After the $48 \mathrm{~h}$ dark acclimation period, cells of both species were located mainly at the surface of the columns (Fig. 3 for C. subsalsa) and both had ceased DVM.

\section{Expt 2-light dependence of DVM}

In this experiment, for which the light was left on continuously, Heterosigma akashiwo exhibited nega-

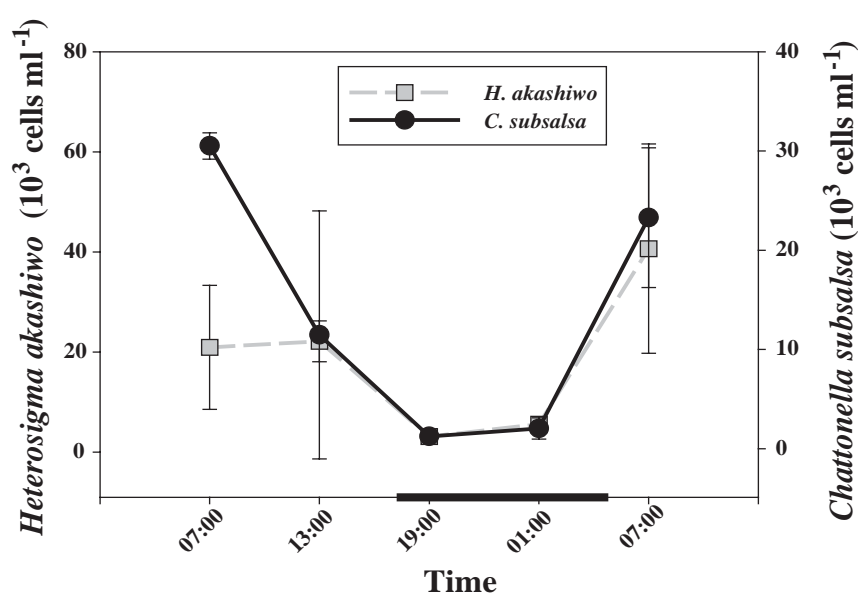

Fig. 2. Chattonella subsalsa and Heterosigma akashiwo. Comparison of cell counts on a linear scale (mean \pm SD) from surface samples from laboratory Expt 1. Black bar on the $X$-axis represents the dark period 


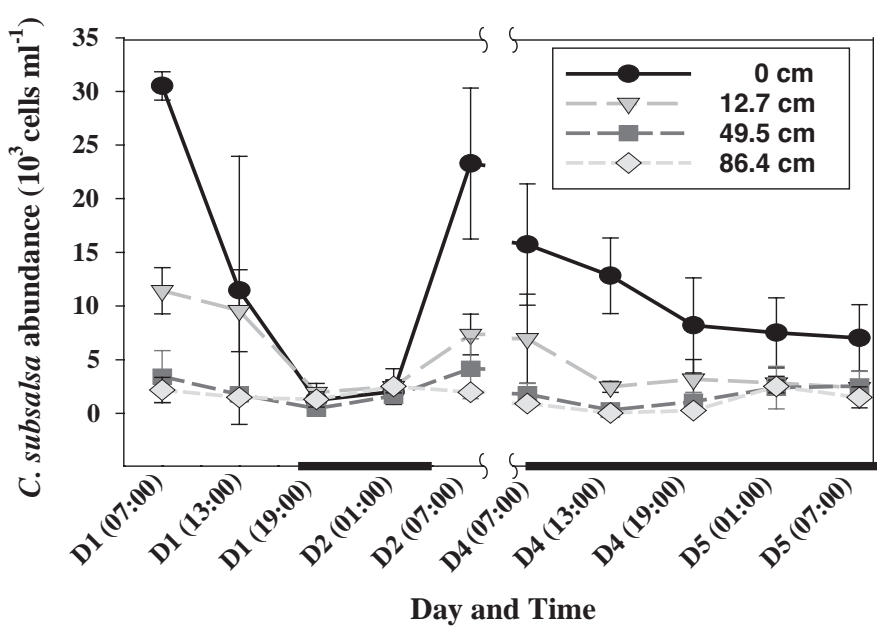

Fig. 3. Chattonella subsalsa. Cell counts on a linear scale $($ mean $\pm \mathrm{SD})$ at 4 depths from the diel vertical migration laboratory Expt 1. Black bars on the $x$-axis indicate dark periods. Data to the left of the $x$-axis scale break were obtained during a 14:10 h light:dark cycle. Cells were then placed in continuous darkness for $48 \mathrm{~h}$ (scale break) before resumption of sampling in continual darkness (right of scale break). D1-D5: Days 1 to 5

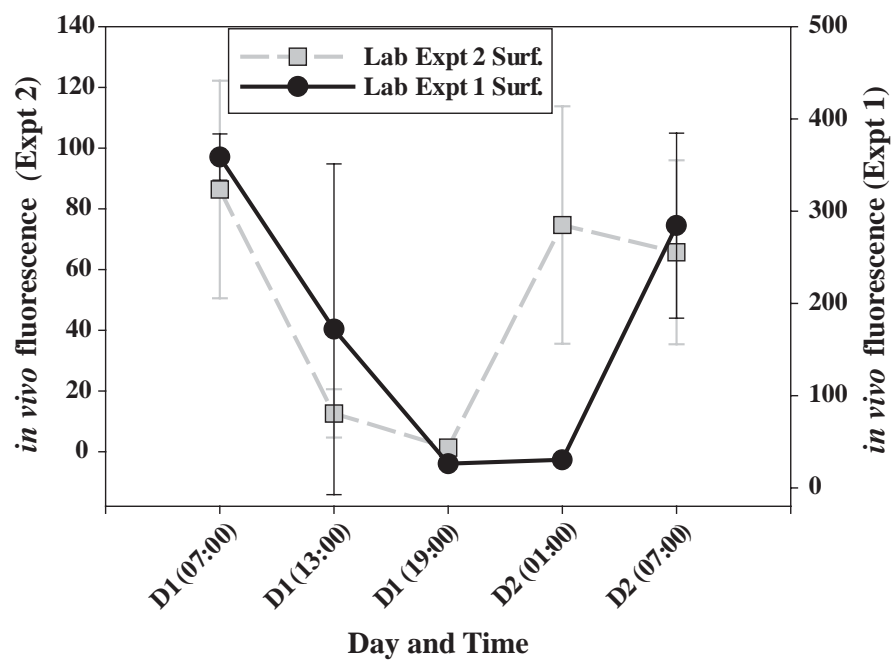

Fig. 4. Chattonella subsalsa. Comparison of in vivo chlorophyll measurements (mean $\pm \mathrm{SD}$ ) at the surface for laboratory Expt 1 (14:10 h light:dark cycle) and laboratory Expt 2 (continuous light)

tive phototaxis and moved as far away from the light as possible by migrating to the bottom of the water column and remaining there (data not shown). Chattonella subsalsa continued to migrate, but its pattern was shifted $6 \mathrm{~h}$ earlier compared to Expt 1 under a 14:10 h light:dark cycle. Cells were found at the surface of the water column at 01:00 h (Fig. 4), compared to $07: 00 \mathrm{~h}$ in the previous light:dark experiment. It was visually apparent that for both species, cells migrated all the way to the bottom of the column.

\section{Field mesocosm experiments}

Expt 1-Chattonella subsalsa bloom

In field Expt 1, Chattonella subsalsa was the dominant species with small amounts of a few dinoflagellate species and ciliates according to initial microscopic cell counts. The water column ( 1 m deep) was highly stratified due to heavy rain in the days before the experiment. Stratification was evident for salinity (Fig. 5e), temperature (not shown), and dissolved nutrients (Fig. 5c). Salinity changes in the mesocosms could be the result of freshwater input via precipitation (from above) or by tidal pumping through the sediments (from below, Fig. 5e). Throughout the entire experiment, phosphate (Fig. 5c), and nitrite plus nitrate (not shown) were highest at the surface (top third) of the water column and followed similar trends, with values ranging from 6 to $14 \mu \mathrm{M}$ for nitrite plus nitrate and 2.9 to $6 \mu \mathrm{M}$ for phosphate. Surface layer dissolved nutrients showed a relatively steady decrease after 07:00 h on the first day until the end of the experiment.

The DVM behavior of the community was apparent in QPCR cell counts for Chattonella subsalsa (Fig. 5a), chl a data (Fig. 5b), and POP (Fig. 5d). QPCR was used to explore the dynamics of C. subsalsa vertical distributions throughout the experiment. The highest concentrations of cells were $3.89 \times 10^{7}$ and $1.61 \times 10^{7}$ cells $\mathrm{l}^{-1}$ at the surface at $13: 00 \mathrm{~h}$ on the 2 successive days of the experiment. There were maxima in the bottom water at 07:00 and 19:00 $\mathrm{h}$ on both days of the experiment (Fig. 5a).

All of the particulate nutrient concentrations were generally higher in the surface waters, ranging from 1.5 to $3 \mu \mathrm{mol} \mathrm{l} \mathrm{l}^{-1}$ for POP (Fig. $5 \mathrm{~d}$ ), 18 to $62 \mu \mathrm{mol} \mathrm{l} \mathrm{l}^{-1}$ for PON, and 200 to $590 \mu_{\mathrm{mol} \mathrm{l}}^{-1}$ for POC over the course of the experiment. PON and POC followed trends similar to those of POP (not shown). The highest surface concentrations were at $13: 00 \mathrm{~h}$ for all 3 particulate measurements over both days, and lowest at 23:00 h. POP (Fig. 5d) and PON (not shown) had similar patterns at the bottom of the water column, being relatively lower at 07:00 and 19:00 $\mathrm{h}$ and slightly higher at 13:00 and 23:00 $\mathrm{h}$ on all days. In contrast, POC decreased steadily on the bottom from 07:00 $\mathrm{h}$ on the first day until 07:00 $\mathrm{h}$ on the second day, at which point it gradually increased until the end of the experiment (data not shown).

Particulate ratios were very similar between the surface and bottom of the water column. PON:POP ratio values ranged from 10 to 50, but were usually 24 in both the top and bottom of the water column (data not shown). POC:PON ratios ranged from 8 to 12, and POC:POP ratios from 120 to 400, again without any obvious difference in trends between the surface and bottom. 


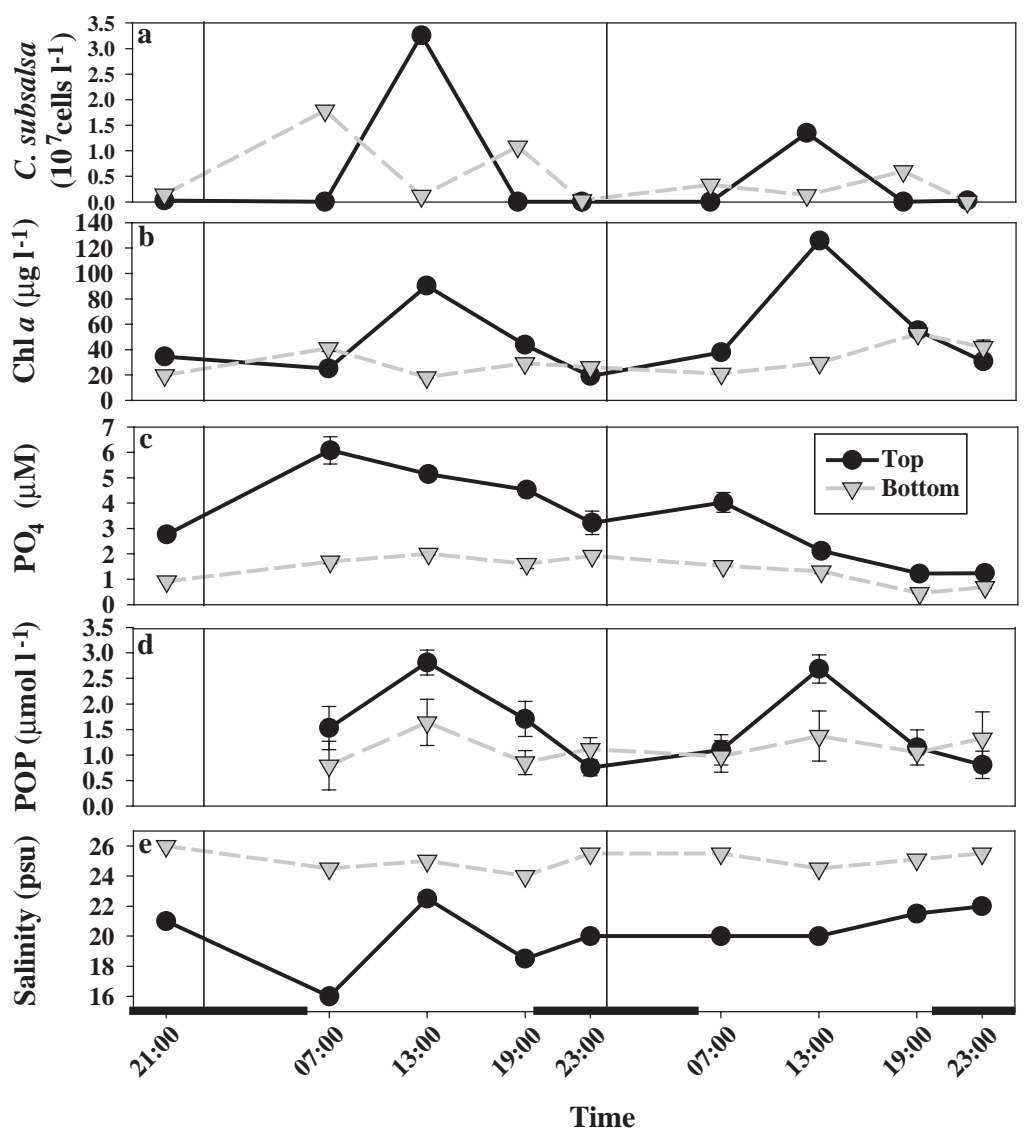

Fig. 5. Parameters from field Expt 1: (a) vertical distribution of Chattonella subsalsa on a linear scale as counted from quantitative real-time PCR, (b) extracted chl $a_{1}$ (c) dissolved phosphate $\left(\mathrm{PO}_{4}\right)$, (d) particulate organic phosphate (POP), and (e) salinity. Data points of all but salinity and C. subsalsa cell counts $(\mathrm{n}=1)$ are mean $\pm \mathrm{SD}$ of triplicate samples. Black bars on the $x$-axis represent dark periods; days separated by vertical lines

A time series of cell vertical distribution profiles at all 3 depths sampled over the $2 \mathrm{~d}$ for field Expt 1 is shown in Fig. 6. Chattonella subsalsa was at the surface at 13:00 $\mathrm{h}$ on both days, and in the bottom of the water column at 07:00 and 19:00 h each day. At 23:00 h, however, no cells were detected by QPCR in the water column. This was the only raphidophyte that was sufficiently abundant in this bloom to track using QPCR.

\section{Expt 2-mixed raphidophyte blooms}

The second mesocosm field experiment was different with regard to its stratification. Unlike the first experiment, salinity and temperature were uniform in the water column $\left(25\right.$ to $30^{\circ} \mathrm{C}, 26$ to $\left.28 \mathrm{ppt}\right)$, without evident stratification (data not shown). In contrast to field Expt 1, $\mathrm{chl} a$ (Fig. 7b) and the particulate nutrients (Fig. 7c,f) did not show any clear trends to indicate diel migration of

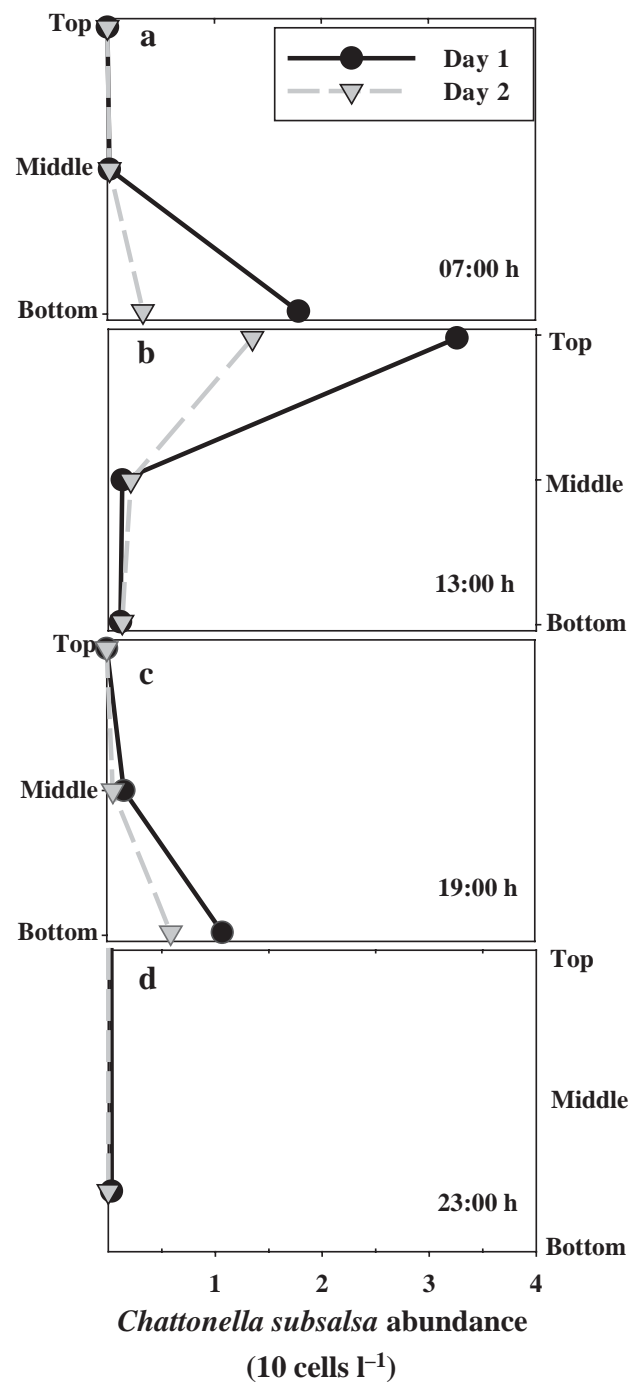

Fig. 6. Chattonella subsalsa. Vertical distribution of cell abundance on log scale as counted from quantitative real-time PCR over time from field Expt 1

the majority of the biomass in the system. In the surface water, POC ranged from 430 to $2500 \mu \mathrm{mol} \mathrm{l}^{-1}$ (Fig. $7 \mathrm{C}$ ), POP from 1 to $10 \mathrm{umol}^{-1}$ (Fig. $7 \mathrm{f}$ ), and PON from 50 to $240 \mathrm{\mu mol} \mathrm{l}^{-1}$ (data not shown). The bottom water had a smaller range of values for the particulates: 1 to $5 \mu \mathrm{mol} \mathrm{l}^{-1}$ for POP (Fig. 7f), 400 to $2000 \mathrm{umol} \mathrm{l}^{-1}$ for POC (Fig. $7 \mathrm{C}$ ), and 50 to $200 \mathrm{\mu mol} \mathrm{l}^{-1}$ for PON (data not shown). Similar trends were observed for all particulates, with highest concentrations at the surface between 07:00 and 13:00 h on the first day. They were then relatively low and stable throughout the experiment, with slight peaks at 07:00 $\mathrm{h}$ in surface water on Days 2 and 3. The highest concentrations of POP and POC were at 13:00 h on Day 1, which corresponded to high biomass present at that time as can be seen in the chl a data (Fig. 7b). 

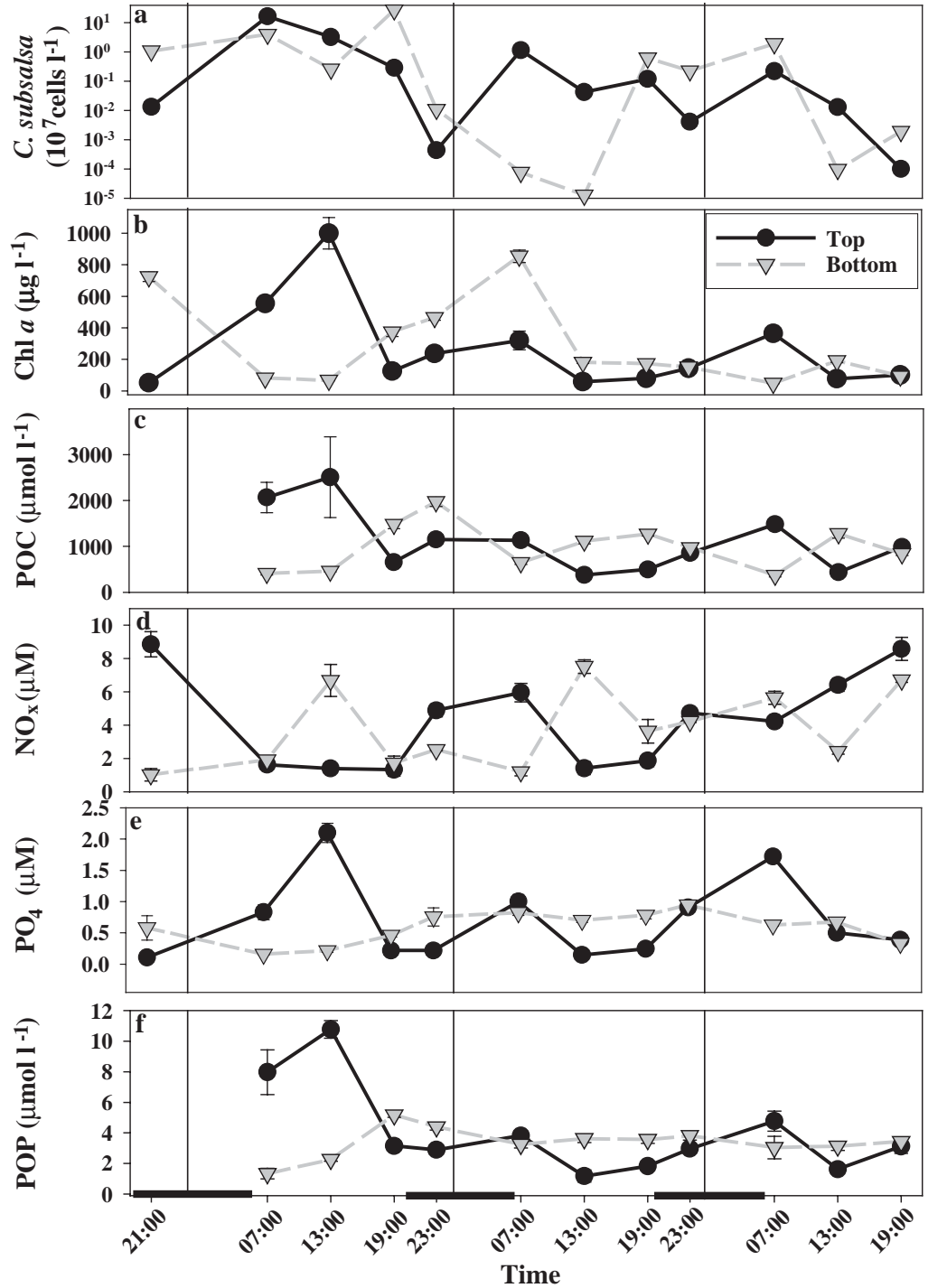

Fig. 7. Parameters measured from field Expt 2: (a) vertical distribution of Chattonella subsalsa on log scale as counted from quantitative real-time

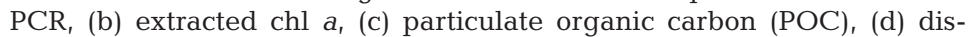
solved nitrate plus nitrite $\left(\mathrm{NO}_{\mathrm{x}}\right)$, (e) dissolved phosphate $\left(\mathrm{PO}_{4}\right)$, and (f) particulate organic phosphate (POP). Data points of all but $C$. subsalsa cell counts $(n=1)$ are mean \pm SD of triplicate samples. Black bars on the $x$-axis represent dark periods; days separated by vertical lines

Dissolved nutrients differed between the surface and the bottom, and varied over time in surface water (Fig. 7d,e). Nitrate plus nitrite concentrations (Fig. 7d) did not exhibit a consistent pattern over the entire experiment, but surface values ranged from 1 to $9 \mu \mathrm{M}$ whereas bottom values ranged from 1 to $6 \mu \mathrm{M}$. Concentrations were highest in surface water at 21:00 h $\left(T_{0}\right)$ and 19:00 h on Day 3. The highest concentrations in bottom water were at 13:00 h on the first $2 \mathrm{~d}$ of the experiment, but this was not noted on the third day. These peaks in the bottom water corresponded to the lowest values for the surface waters. Dissolved phosphate con- centrations (Fig. 7e) ranged from 0.1 to $2 \mu \mathrm{M}$ and were highest at the surface of the water column and at 07:00 h on Days 2 and 3, but were highest at 13:00 h on Day 1. In bottom water, values did not follow a diel cycle and stayed $\sim 0.5 \mu \mathrm{M}$ over the whole experiment.

The POC:POP ratios in field Expt 2 ranged from 100 to 450 at the bottom of the water column and from 200 to 400 at the surface (Fig. 8a). More specifically, POC: $\mathrm{POP}$ ratios at the surface ranged from 200 to 275 for the first 3 time points, and then increased to 375 before dropping to 300 for the duration of the experiment. PON:POP ratios (Fig. 8b) varied from 17 to 48 , with the lowest ratio at the bottom at 07:00 $\mathrm{h}$ on Days 2 and 3. POC:PON ratios (Fig. 8c) varied from 7.5 to 10.5. On Day 1, the surface had a higher POC:PON ratio at $07: 00$ and 13:00 $\mathrm{h}$ relative to the bottom. It was higher at the bottom at 19:00 h on Day 1, and then after 23:00 h on Day 1 the ratios became similar at the surface and subsurface, suggesting a nitrogen replete condition similar to the first field experiment.

The raphidophyte migration pattern follows the same basic trends as in field Expt 1, although cell densities were considerably greater in Expt 2 (Figs. 5a \& 9). For the first $2 \mathrm{~d}$, Chattonella subsalsa was at the surface at 07:00 and 13:00 h (Fig. 9), but by the end of the experiment the composition of the bloom had changed to a system dominated by autotrophic dinoflagellates. Gyrodinium instriatum was the numerically dominant dinoflagellate species (K. J. Coyne unpubl.). Over the course of the experiment, cell abundances of Heterosigma akashiwo and C. subsalsa followed the same trends in both the top (Fig. 9a) and bottom (Fig. 9b) of the water column. Highest cell abundances for both species were in surface waters at 07:00 h. In field Expts 1 and 2, nutrient concentrations and cell densities were similar inside and outside the mesocosms (data not shown). Both field experiments contained potentially harmful algal species, but there was no evidence of fish kills or respiratory distress outside the mesocosms (no fish were present in the mesocosms themselves).

\section{DISCUSSION}

Field and laboratory experiments revealed that raphidophytes from the DIB vertically migrated in both 

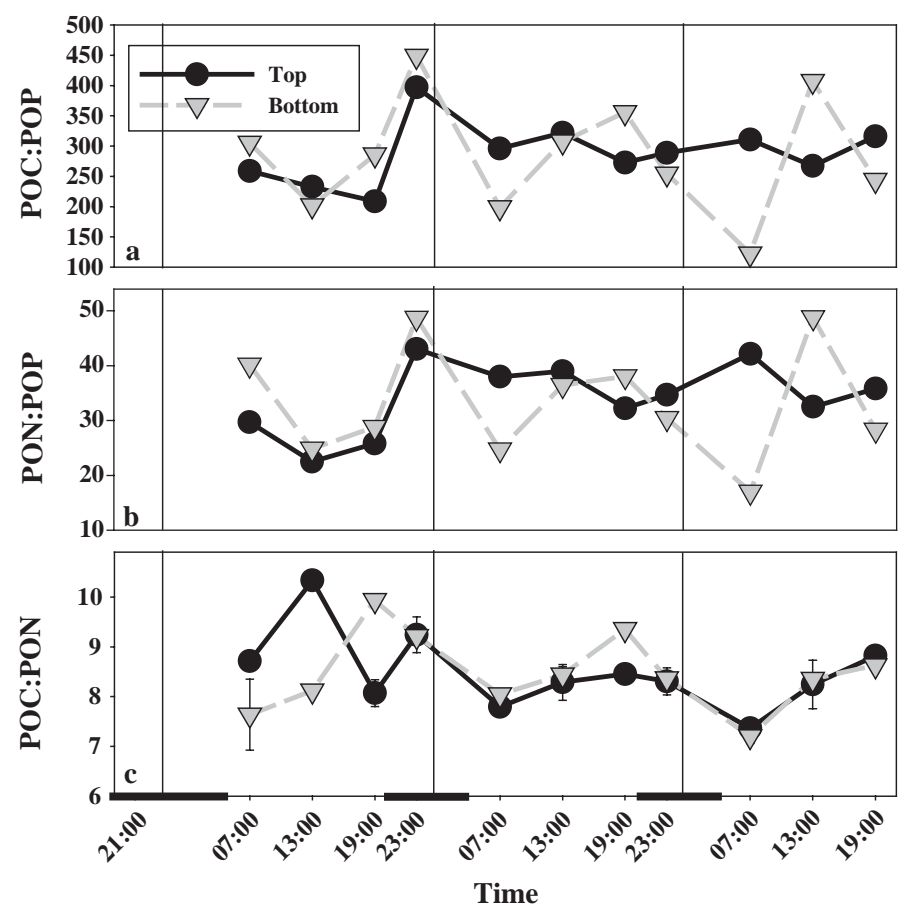

Fig. 8. Particulate ratios (POC, PON, POP) from field Expt 2. For POC:PON, data points are mean \pm SD. Black bars on the $X$-axis represent dark periods; days separated by vertical lines

a uniform well-mixed water column and under stratified conditions, even after being isolated and maintained in culture removed from natural environmental stimuli for over 2 yr. Therefore, this behavior seems to have a deeply rooted genetic basis, and is likely to confer some competitive advantage in the DIB. Possible reasons for the evolutionary persistence of this behavior in a shallow estuary include nutrient uptake, grazing avoidance, or evasion of oxidative stress due to increased production of reactive oxygen species (ROS) near the surface during the day (Kim et al. 2004, 2005).

Under the 14:10 h light:dark cycle, Chattonella subsalsa and Heterosigma akashiwo accumulated at the surface of the water column at the beginning of the light phase (Fig. 2). Under normal non-bloom conditions there is ample light (up to $600 \mu \mathrm{mol}$ quanta $\mathrm{m}^{-2}$ $\mathrm{s}^{-1}$ ) such that these algae are not light limited at the surface of the DIB (M. Warner pers. comm.); however, under dense bloom conditions, these species may be competing with each other for light. C. subsalsa had a consistent and distinct migratory pattern in every experiment, whether in the laboratory or in the field. It was found at the surface between 07:00 and 13:00 $\mathrm{h}$, in the bottom third of the water column around 19:00 h, and then at the sediments and very bottom of the water column during the night. The one exception to this was that when in continual darkness, cells were continuously found at the surface.
In contrast, Heterosigma akashiwo did not maintain a consistent pattern in the laboratory when placed in either full light or complete darkness. This suggests that $H$. akashiwo has the ability to sense and react to its light environment (i.e. phototaxis) and it is not regulated by endogenous rhythms in the same way that Chattonella subsalsa apparently is (see discussion below). This is contrary to the findings of Takahashi \& Hara (1989), who concluded that the Japanese $H$. akashiwo strain they investigated had an 'internal clock'. This difference is an as yet unexplored aspect of behavioral variability within a species or population, and in fact many different $H$. akashiwo ecophenotypes have been described (Watanabe et al. 1982, Twiner et al. 2001). Different behavioral mechanisms among separate populations and strains (ecophenotypes) may play a pivotal role in allowing the spatial expansion of these potential harmful species to new environmental systems.

When cells were in complete darkness, both species (Chattonella subsalsa and Heterosigma akashiwo)

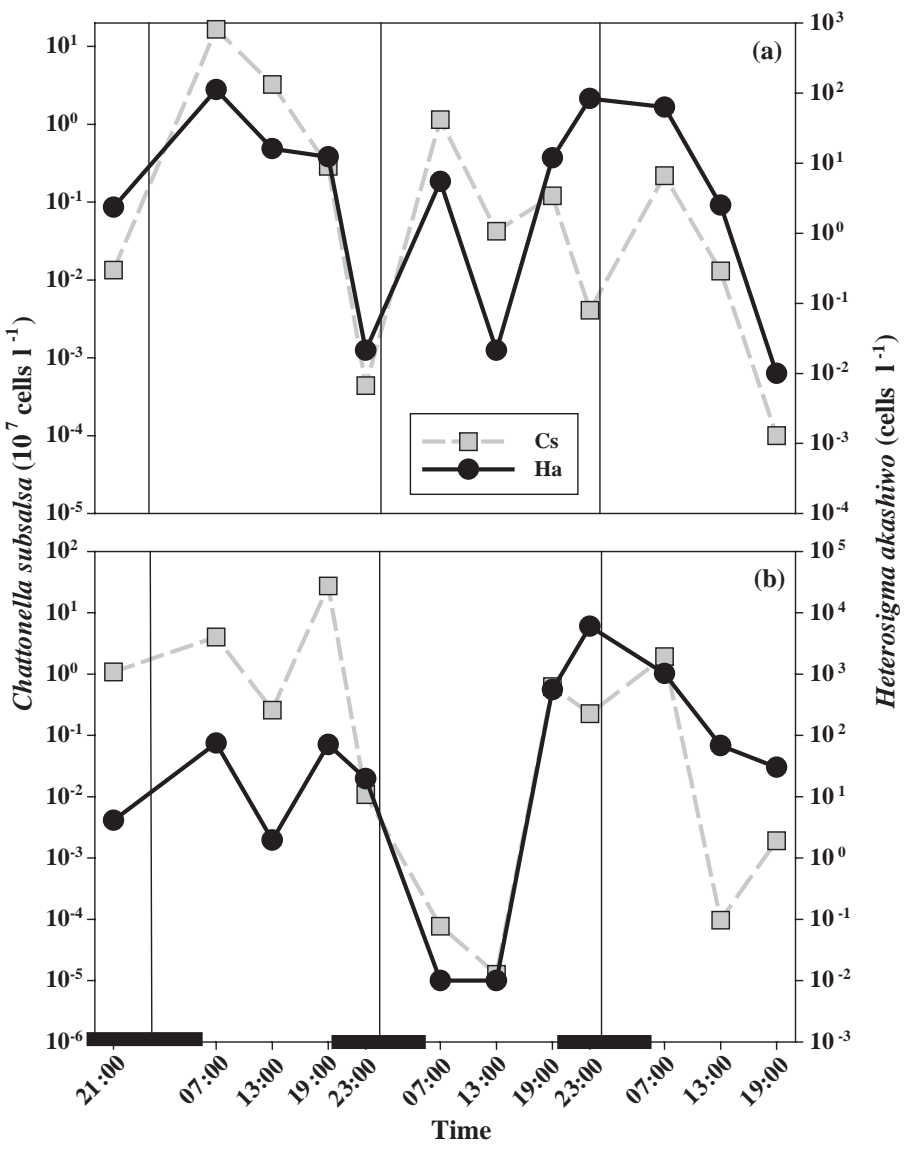

Fig. 9. Chattonella subsalsa and Heterosigma akashiwo. Comparison of cell counts on a log scale (quantitative realtime PCR) for field Expt 2. Black bars on the $x$-axis represent dark periods; days separated by vertical lines. (a) Surface, (b) bottom. Ha: H. akashiwo, Cs: C. subsalsa 
remained at the surface of the water column, perhaps attempting to access whatever light they could. This suggests that they may have been orienting by some other means, such as geotaxis (the movement of an organism in response to gravity in the absence of light; Cullen \& Horrigan 1981) (Fig. 3, C. subsalsa as an example).

In continuous light, Chattonella subsalsa continued to migrate in the absence of a 14:10 h light:dark cycle. The timing of its movement shifted, however, so that cells were back at the surface $6 \mathrm{~h}$ earlier than when under the 14:10 h light:dark cycle. This suggests that C. subsalsa has an endogenous clock that may have to be reset each day by the light:dark cycle. Consequently, when the light:dark cycle was changed, cells started to shift their movements temporally (see Fogg \& Thake 1987). Heterosigma akashiwo seemed to exhibit negative phototaxis and stayed at the bottom of the water column throughout the experiment (data not shown). The results of the laboratory experiments suggested that there were possible differences in the ecological niches and migratory mechanisms for these 2 species of DIB raphidophyte, at least under varying light conditions in the laboratory. Experimental conditions in the laboratory may have potentially affected some results, as the diameter of the column used was relatively small. However, field experiments were conducted with a column that was much larger $(67.5 \mathrm{~cm}$ vs. $10.6 \mathrm{~cm}$ ) and the results from both the laboratory and field were strikingly similar. We concluded that there were no appreciable enclosure effects from conducting the experiment in this manner.

While the DIB are shallow, they can be highly stratified in terms of nutrients, salinity and temperature. In a stratified system such as the DIB, different sources of nutrients could be expected to lead to elevated concentrations at different depths. Rozan et al. (2002) showed that the sediments of the DIB release bioavailable phosphate. Sediments could also serve as a source of bioavailable micronutrients such as trace metals (Church \& Scudlark 1998). In contrast, the low salinity surface layer could receive nutrient inputs from freshwater storm runoff, especially in areas of high fertilizer use or sewage inputs. It is evident that migrating flagellates could be able to take advantage of any of these vertically stratified nutrient sources, as they swim all the way down to the sediments and back up to the surface throughout the course of a day.

In field Expt 1, phytoplankton were nutrient replete due to the high concentration of dissolved nutrients in the surface waters, and concentrations never decreased to approach detection limits. This is also supported by the lack of differences present in the particulate nutrient ratios between the top and the bottom. However, during field Expt 2, large differences were found between POC:PON ratios at the top and bottom third of the water column on Day 1, and between PON:POP and POC:POP ratios on the last $2 \mathrm{~d}$. The largest differences between the surface and the bottom were found in the POC:POP ratios. We expected that the POC:POP ratios would increase during the day as carbon was fixed by the bloom. If the cells were taking up phosphate from benthic sources at night, POC:POP ratios would be expected to decrease. This did not seem to be the case, and our original hypothesis regarding phosphate uptake at night from anoxic sediment fluxes was not supported by these field studies. Instead, the phytoplankton community appeared to become slightly enriched with $P$ relative to $\mathrm{C}$ when they were near the surface during the day. However, it must be noted that the particulates are not raphidophyte- or alga-specific, but represent the whole plankton community as well as non-living material; therefore, we cannot rule out the possibility of phosphorous uptake by certain parts of the algal community based on these experiments.

In field Expt 2, Chattonella subsalsa could be followed throughout the entire water column until 23:00 $\mathrm{h}$, when it disappeared from the water column on both sampling days. The design of our mesocosm sampling ports did not allow sampling of the benthic boundary layer, and the nephloid layer makes this section of the water column extremely hard to sample quantitatively. We avoided this layer in order keep from contaminating our particulate samples with sediment particles. Nevertheless, available circumstantial evidence (Fig. 6) and our qualitative microscopic observations strongly suggest that both C. subsalsa and Heterosigma akashiwo cells migrated all the way to the sediment surface at night.

The effects of grazing were not studied in these experiments, but could provide another advantage to vertical migration in a shallow water column. The DIB have large populations of epibenthic mysid shrimp and harpacticoid copepods (M. A. Doblin unpubl.), which are known to spend daylight hours on the sediment surface but move into the upper water column to feed at night (Cronin et al. 1962, Walker 1989). The opposite migratory behavior seen in the raphidophyte species examined in this study may confer an advantage by minimizing grazing losses compared to non-swimming species.

In addition to grazer avoidance, vertical migration of raphidophyte species may be an adaptive response to oxidative stress. Kim et al. (2004) suggested that many raphidophytes produce higher levels of ROS during the day (as a result of photosynthesis) than at night. Since our data demonstrate that Heterosigma akashiwo and Chattonella subsalsa are located at the surface during the day, it is quite possible that raphido- 
phytes escape self-produced and potentially harmful ROS stress at night by vertical migration.

All experiments in the present study were conducted under nutrient replete conditions, and the nutrient measurements were determined for the entire community. This may be why an uptake of nutrients was not clearly apparent. The combined effects of nutrient limitation, grazers, ROS and light on raphidophyte species could be clarified by unialgal laboratory experiments and may be a good avenue for future research. QPCR was especially suited for our vertical migration experiments since raphidophytes do not preserve well. In addition, performing large numbers of timeconsuming microscopic counts during intensive, multiple parameter sampling is not practical. In contrast, DNA can be easily frozen and thus preserved virtually indefinitely. QPCR will even detect minute cell densities that would not be possible with traditional microscopic techniques, and so is uniquely suited for enumerating cells at background levels and in pre- and post-bloom situations (Popels et al. 2003).

One disadvantage of molecular counting techniques is that DNA extracted from environmental estuarine water samples is often contaminated with humic acids and other organic compounds that may potentially inhibit the PCR. We were able to correct for inhibition by including the plasmid pGEM in the extraction buffer as an internal standard (Coyne et al. in press). The pGEM plasmid DNA was extracted with the water sample DNA, and amplified using plasmid-specific primers and probe. By keeping the level of pGEM standard DNA constant between samples, we could more accurately calculate cell densities by normalizing $\mathrm{Ct}$ values generated from species-specific amplification reactions to $\mathrm{Ct}$ values from the pGEM internal standard amplification. The use of the same internal standards in different field experiments allowed them to be quantitatively compared with each other.

The primary goal of this study was to begin to understand how and where blooms of these different species move within the water column throughout the day, as this behavior has important implications for sampling strategies. Environmental monitoring samples are sometimes collected only at or near the surface of the water column. For species that migrate vertically, this could cause the frequency and density of blooms to be under- or over-reported, depending on the timing of sampling during the day. Vertical migration behavior needs to be understood and considered so that routine monitoring can accurately sample potentially harmful species. Red tide blooms of toxic raphidophytes have grown to be a global ecological and economic concern. The use of molecular tools such as QPCR allows us to obtain a more complete picture of the distribution and behavior of these phytoplankton. A better understand- ing of the basic ecological functions and niches of these multiple sympatric HAB species is essential in order to explore the causes of destructive blooms in the DIB, and elsewhere around the world.

Acknowledgements. Thanks to L. Salvitti, J. Scudlark, K. Savidge, M. Warner, S. Coyne and M. Madden for assistance with sampling, experimental set up and data interpretation, to the Marine Operations Building at the University of Delaware for building columns, and to Y. Zhang, E. Whereat and the Delaware Volunteer Phytoplankton Monitoring Group for assistance with determining bloom location. Also thanks to J. Dershem and B.Winkler for the use of their docks and 3 anonymous reviewers for helpful comments. This project was supported by a Center for the Inland Bays grant to D.A.H., and EPA STAR ECOHAB grant R83-1041 to D.A.H., M.A.D., K.J.C., and S.C.C.

\section{LITERATURE CITED}

Bourdelais AJ, Tomas CR, Naar J, Kubanek J, Baden DG (2002) New fish-killing alga in coastal Delaware produces neurotoxins. Environ Health Perspect 110:465-470

Brand LE, Guillard RRL, Murphy LS (1981) A method for the rapid and precise determination of acclimated phytoplankton reproduction rates. J Plankton Res 3:193-201

Church T, Scudlark JR (1998) Trace metals in estuaries: a Delaware Bay synthesis. In: Allen HE, Garrison AW, Luther GW III (eds) Metals in surface waters. Ann Arbor Press, Chelsea, MI, p 1-21

Coyne KJ, Hutchins DA, Hare CE, Cary SC (2001) Assessing temporal and spatial variability in Pfiesteria piscicida distributions using molecular probing techniques. Aquat Microb Ecol 24:275-285

Coyne KJ, Handy SM, Demir E, Whereat E, Hutchins DA, Portune KJ, Doblin MA, Cary SC (in press) Improved quantitative real-time PCR assays for enumeration of harmful algal species in field samples using an exogenous DNA reference standard. Limnol Oceanogr Methods

Cronin LE, Daiber JC, Hulbert EM (1962) Quantitative seasonal aspects of zooplankton in the Delaware River Estuary. Chesapeake Sci 3:63-93

Cullen JJ, Horrigan SG (1981) Effects of nitrate on the diurnal vertical migration, carbon to nitrogen ratio, and the photosynthetic capacity of the dinoflagellate Gymnodinium splendens. Mar Biol 62:81-89

Cutter GA, Radford-Knoery J (1991) Determination of carbon, nitrogen, sulfur, and inorganic sulfur species in marine particles. In: Hurd DC, Spencer DW (eds) Marine particles: analysis and characterization. American Geophysical Union, Washington, DC

Dempster EL, Pryor KV, Francis D, Young JE, Rogers HJ (1999) Rapid DNA extraction from ferns for PCR-based analyses. Biotechniques 27:66-68

Eppley RW, Holm-Hanson O, Strickland JDH (1968) Some observations on vertical migration of dinoflagellates. J Phycol 4:333-340

Flaim G, Rott E, Corradini F, Toller G, Borghi B (2003) Longterm trends in species composition and diurnal migration of dinoflagellates in Lake Tovel (Trentino, Italy). Hydrobiologia 502:357-366

Fogg GE, Thake BT (1987) Algal cultures and phytoplankton ecology, 3rd edn. University of Wisconsin Press, Madison, WI 
Guillard RRL, Ryther JH (1962) Studies of marine planktonic diatoms. I. Cyclotella nana hustedt and Detonula confervacea. Can J Microbiol 8:229-239

Haque SM, Onoue Y (2002) Variation in toxin compositions of two harmful raphidophytes, Chattonella antiqua and Chattonella marina, at different salinities. Environ Toxicol 17:113-118

Heid CA, Stevens J, Livak KJ, Williams PM (1996) Real time quantitative PCR. Genome Res 6:986-994

Horsley \& Witten Inc (1998) Assesment of nitrogen loading to the Delaware Inland Bays. Report to the Delaware Inland Bays National Estuary Program. Nassu, DE

Kim D, Nakamura A, Okamoto T, Komatsu N, Oda T, Ishimatsu A, Muramatsu T (1999) Toxic potential of the raphidophyte Olisthodiscus luteus: mediation by reactive oxygen species. J Plankton Res 21:1017-1027

Kim D, Watanabe M, Nakayasu Y, Kohata K (2004) Production of superoxide anion and hydrogen peroxide associated with cell growth of Chattonella antiqua. Aquat Microb Ecol 35:57-64

Kim D, Watanabe M, Nakayasu Y, Kohata K (2005) Changes in $\mathrm{O}_{2}{ }^{-}$and $\mathrm{H}_{2} \mathrm{O}_{2}$ production by Chattonella antiqua during diel vertical migration under nutrient stratification. Aquat Microb Ecol 39:183-191

Kimura T, Watanabe M, Kohata K, Sudo R (1999) Phosphate metabolism during diel vertical migration in the raphidophycean alga, Chattonella antiqua. J Appl Phycol 11: 301-311

Lebo ME, Sharp JH (1992) Phosphorus distributions along the Delaware: an urbanized coastal plain estuary. Estuaries 16:291-302

Lee KS, Ishimatsu A, Sakaguchi H, Oda T (2003) Cardiac output during exposure to Chattonella marina and environmental hypoxia in yellowtail (Seriola quinqueradiata). Mar Biol 142:391-397

Livak KJ, Schmittgen TD (2001) Analysis of relative gene expression data using real-time quantitative PCR and the $2^{-\Delta \Delta \mathrm{Ct}}$ method. Methods 25:402-408

Marshall JA, de Salas M, Oda T, Hallegraeff G (2005) Superoxide production by marine microalgae. Mar Biol 147:533-540

Munday BL, Hallegraeff GM (1998) Mass mortality of captive southern bluefin tuna (Thunnus maccoyii) in April/May 1996 in Boston Bay, South Australia: a complex diagnostic problem. Fish Pathol 33:343-350

Odebrecht C, Abreu PC (1995) Raphidophycean in southern Brazil. IOC UNESCO, Harmful Algal News 12/13:4

Popels LC, Cary SC, Hutchins DA, Forbes R, Pustizzi F, Gobler CJ, Coyne KJ (2003) The use of quantitative polymerase chain reaction for the detection and enumeration

Editorial responsibility: David Caron,

Los Angeles, California, USA of the harmful alga Aureococcus anophagefferens in environmental samples along the United States East Coast. Limnol Oceanogr Methods 1:92-102

Price KS (1998) A framework for a Delaware Inland Bays environmental classification. Environ Monit Assess 51: 285-298

Rozan TF, Taillefert M, Trouwborst RE, Glazer BT and 5 others (2002) Iron-sulfur-phosphorus cycling in the sediments of a shallow coastal bay: implications for sediment nutrient release and benthic macroalgal blooms. Limnol Oceanogr 47:1346-1354

Smayda TJ, Borkman D (2003) Long-term bloom behavior of Prorocentrum species in Narragansett Bay. 2nd Symp Harmful Marine Algae in the US. December 8-13, 2003, Marine Biological Laboratory, Woods Hole, MA

Takahashi M, Hara Y (1989) Control of diel vertical migration and cell division rhythm of Heterosigma akashiwo by day and night cycles. In: Okaichi T, Anderson DM, Nemoto $\mathrm{T}$ (eds) Red tides: biology, environmental science, and toxicology. Elsevier Science Publishing, New York, p 265-268

Twiner MJ, Trick CG (2000) Possible physiological mechanisms for production of hydrogen peroxide by the ichthyotoxic flagellate Heterosigma akashiwo. J Plankton Res 22:1961-1975

Twiner MJ, Dixon SJ, Trick CG (2001) Toxic effects of Heterosigma akashiwo do not appear to be mediated by hydrogen peroxide. Limnol Oceanogr 46:1400-1405

Walker WJ (1989) Abundance and distribution of Neomysis americana in the Delaware river estuary. MS thesis, University of Delaware, Neward, DE

Watanabe MM, Nakamura Y, Mori S, Yamochi S (1982) Effects of physio-chemical factors and nutrients on the growth of Heterosigma akashiwo Hada from Osaka Bay, Japan. Jpn J Phycol 30:279-288

Watanabe M, Kohata K, Kimura T, Takamatsu T, Yamaguchi $\mathrm{S}$, Ioriya $\mathrm{T}$ (1995) Generation of a Chattonella antiqua bloom by imposing a shallow nutricline in a mesocosm. Limnol Oceanogr 40:1447-1460

Welschmeyer NA (1994) Fluorometric analysis of chlorophyll $a$ in the presence of chlorophyll $b$ and phaeopigments. Limnol Oceanogr 39:1985-1992

Whereat ED (2003) Phytoplankton monitoring report. Volunteer Phytoplankton Monitoring Group, Delaware Inland Bays Citizen Monitor Program. University of Delaware, Lewes, DE

Yang CZ, Albright LJ, Yousif AN (1995) Oxygen-radicalmediated effects of the toxic phytoplankter Heterosigma carterae on juvenile rainbow trout Oncorhynchus mykiss. Dis Aquat Org 23:101-108

Submitted: March 5, 2005; Accepted: August 3, 2005 Proofs received from author(s): September 5, 2005 